Ethiopian Journal of Environmental Studies \& Management 8(5): 507 - 516, 2015.

ISSN:1998-0507

doi: http://dx.doi.org/10.4314/ejesm.v8i5.4

Submitted: January 14, 2015

Accepted: June 22, 2015

\title{
USING HEDONIC PRICE MODEL TO ESTIMATE EFFECTS OF FLOOD ON REAL PROPERTY VALUE IN LOKOJA NIGERIA
}

\author{
EGBENTA, I.R., ${ }^{1}$ UDO, G.0. ${ }^{2}$ AND *OTEGBULU, A.C. ${ }^{3}$ \\ ${ }^{1}$ Department of Estate Management, University of Nigeria, Enugu Campus, Nigeria \\ ${ }^{2}$ Department of Estate Management, University of Uyo, Nigeria \\ ${ }^{3}$ Department of Estate Management, University of Lagos, Akoka, Nigeria
}

\begin{abstract}
The perceived risk associated with flood hazard has increased its awareness especially among those living within the flood prone areas. There is paucity of information on the effects of flood hazard on property values in Nigeria. The aim of the study is to assess the effects of flood on property value in Lokoja using hedonic price model with a view to contributing to the existing literature. The study uses a total of 50 residential homes that were sold in Lokoja, Nigeria between 2010 and 2012. The study used quantitative data from property transactions before and after the floor disaster and related them with the affected properties to estimate the average effects of the disaster on property value. Data from the Ministry of Lands and Urban development as well as the State Emergency Management Agency were used. Distances were measured in metres from the centroid of the building to the edge of the river and roads using Global Positioning System. The result of the estimation shows that property located within the floodplain are lowers in value by an average of $\$ 493$, 408 which represents 6.8 percent reduction in sales price for an average value house. The study adds to the understanding of the magnitude of the damage caused by flood on real property investment in Nigeria.
\end{abstract}

\section{Introduction}

Nigeria is located in an environment that has not been prone to serious natural disaster such as flood, earthquake, landslide, tsunami, high tide, hurricane, volcanic eruption and so on. Even thought natural disasters are occurring in Nigeria, it is not as serious as compared to countries like United State, Japan, China etc. However, the most common of the natural disasters in Nigeria are desertification, coastal flooding and erosion (Nigeria Disaster Statistics, 2010). Nevertheless, other environmental problems facing Nigeria are oil pollution due to equipment failure and vandalization of pipelines, and

*Corresponding author: Egbenta, I.R.

Email: idu.egbenta@unn.edu.ng domestic waste in urban areas, which are man-made. In this respect, both the citizen and the government of Nigeria do not understand the magnitude of the adverse effects of natural disasters and its prevention investment as in other parts of the world where there is frequent disaster. In this regard, citizens and the government pay insufficient attention to issues of disasters.

However, between September and October 2012, the torrential rainfall hit the entire low land areas of Nigeria resulting in flooding along most rivers and streams in the country, which were very devastated (Al-Amin, 2013). This historic flooding has 
increased awareness of flood hazard in Nigeria, especially those living within the flood prone areas. The Nigerian Emergency Management Agency (NEMA) reported that the total damage caused by flooding in 2012 is in the sum of $\$ 2.6$ trillion. It is estimated that about 597,476 houses were damaged, 2.1 million people were displaced and provided with temporary shelter and 7 million people were affected, and 363 people died during the period (Punch, 2013).

Samaraweera et al. (2010) argues that the economic loss from flood incidence creates a considerable burden on economy due to the financial and the physical risk and uncertainty in economic decision making. In this instance, it is imperative to know the accurate cost of the previous disaster. The Royal Institution of Chartered Surveyors (RICS) (2010) predicted increased flood events due to change in weather patterns, the amount of new buildings on low lying areas in recent years, and other local factors. Many properties previously not at risk of flooding, are currently affected by flood. Thus, to help researchers and policy makers in assessing national progress in reducing vulnerability to flood hazards, reasonably accurate assessment of flood damage are needed. Lack of insurance policies on real property is a national problem. Most public and privates properties are not insured. In an event of natural disaster, victims rely on the government to compensate them for their loss.

There have been several studies on flood damages estimation (Dei-Tutu, 2002; Bin and Polasky, 2004; Okagawa and Hibiki, 2011; Jongman et al., 2012). The general consensus of these studies is that properties located within the flood plan are lower in value than properties located outside the flood plains or flood prone locations. It is interesting to note that these studies are in the developed countries where there are histories of flood hazard and many property owners take up insurance policies for the property. There is paucity of information on the effects of flood hazard on property values in Nigeria. Therefore, the aim of the study is to assess the effects of flood on property value in Lokoja using hedonic price model with a view to contributing to the existing literature on the subject. The proposition is that quality assessment of the risk impacts of flood will facilitate countries to plan adaptation measures and adapt effectively.

\section{Study Area}

Lokoja is located in the North Central part of Nigeria and presently it is the State capital of Kogi State. It is confluence town where the two major rivers (Niger and Benue) that traverse Nigeria, meet (see figure 1). The rivers Niger-Benue trough is a lowland area which divides the subhumid zone into three parts. The flood plains of the Niger and Benue river valleys in Lokoja have the hydromorphic soils which contain a mixture of coarse alluvial and colluvial deposits. The general relief is undulating and characterized by high hills with land rises from about 300 metres above the sea level along the Niger-Benue confluence, to the heights of between 300 and 600 metres above sea level in the uplands. The 2012, flood disaster in Nigeria hit Lokoja greatly. Effect the flood was felt in the southern part of the river as it flow downward and empty into the Atlantic Ocean. A total of 73,000 people were displaced and 5 people died in Lokoja (Red Cross, 2012). Places where flooding occur, houses and villages are swept away besides destruction of farmland and out-break of diseases leading to serious epidemics and drowning. 


\section{Literature}

The incidence of flood is the resultant effect of climate change and global warning. Kolawole et al. (2011) believe that developing countries are already suffering from the impacts of climate change and are the most vulnerable to further change. The most vulnerable areas are the lowland areas and waterfront properties. It is believed that waterfront affects property values positively. Clapper and Caudill (2014) used hedonic analysis to show that water clarity has a significant effect on lakefront property values in the Near North Ontario, Canada. The results indicate that buyers are willing to pay about $2 \%$ more for each 1 -foot increase in water clarity. Lansford and Jones (1995) studied shoreline and near -the -lake properties to analyse recreational and aesthetic value of water using hedonic price. The study indicates that recreational value characteristics of housing is the proximity to waterfront is the most important as waterfront properties command a premium, but marginal recreation and aesthetic price falls rapidly with increasing distance. Water has a characteristics of public good and nonmarket uses, does efficient allocation is difficult to attain and therefore individual cannot be prevented from consuming it. The recreational and aesthetic use value of water can be estimated with nonmarket valuation methods such as the contingent and travel cost method Egbenta and Udo (2013).

In spite of the positive externality of waterfront to property value, there also pose some negative externality to property value. Cho et al. (2011) found that the effects of both the degraded river and its contributing streams on property values are perceived as negative externalities by watershed residents in Tennessee who experienced only harmful effects from the pollution. Bin and Kruse (2006) have shown that a common finding from several studies is that location of property within floodplains lowers property value anywhere from 4 to 12 percent of average. Consideration in the measurement of damage or economic risk associated with environmental disaster, Dorfman et al., (2006) argue that an interesting issue in the direct measure of risk is a test of market rationality. That is whether homeowners' valuations of risk match the observed costs of risk reduction. This information could make a valuable contribution to the debate over the objectivity of the public's perceptions of environmental risk. In the same line of thought, Zhou et al. (2013) argue that flood risk analysis is performed on the basis of a flood risk assessment framework estimating both hazard and vulnerability characteristics of the area under the investigated adaptation strategy. They stress that the environmental economic analysis applies a hedonic valuation approach to capture at least a substantial part of the value of externalities related to the urban water infrastructure. Following this explanation, Scawthorn et al (2006) argue that in estimating direct loss from flood damage two inputs to the damage module are required to estimate building damage: the building occupancy type and first floor elevation, which typically include design levels; and the depth of flooding. These factors are not necessary in the study because the goal of the study is not to determine the total damage by flood hazard rather the effects of flood on property value.

However, if the value of damage to property is contemplated, the value of flood damage in property is based on either replacement cost value or actual cash value. Replacement cost value (RCV) is the cost to replace that part of a building that is 
damaged (without depreciation). Replacement cost would be calculated through the values of physical harm to the buildings, instruments and infrastructure facilities. Scawthorn et al. (2006) argue that the algorithm for estimating direct physical damage to the general building stock is quite simple, and is computed for each occupancy class in a given census block, with default damage functions along with estimated water depths either riverine or coastal to determine the associated percent damage. The estimated percent damage is then multiplied by the total replacement value or the depreciated replacement value of the occupancy class in question to produce estimates of total damage, or total depreciated damage.

Dei-Tutu (2002) estimate the effects of flood hazards on residential property values, using hedonic property price function in Pitt County, North Carolina. The study used data set of 5,122 singlefamily residential home sales between January 1998 and June 2002. The result of the study shows that an average house located in a floodplain is discounted by 6.6 percent of the property value, while the capitalized insurance premium value represents approximately 4 percent of the house's selling price. Bin and Kruse (2006) estimate the effects of flood hazard on residential property values using a hedonic property price method. The results of the study indicate that on average property values is $5-10 \%$ lower if located within a flood zone that is not subject to wave action. However, location within a flood zone that is vulnerable to wave action is associated with higher property values. The study also finds that, in most inland areas, price differentials for flood risk are roughly equivalent to the capitalized value of flood insurance premiums. Dorfman, Keeler and Kriesel (2006) believe that because risk of natural disaster is not directly observable, researchers have used hedonic models to measure the value of changes in observable variables (proxies) closely correlated with the underlying risk being studied. Okagawa, and Hibiki (2011) estimated hedonic land price model by two-stage estimation in Tokyo metropolitan government. The result of the study shows that land price is much higher in non flood prone areas. The general agreements from these review of previous studies is that flood disaster affects property negatively.

\section{Methodology}

Data used in the study were collected from field survey and documented data on flood analysis from Ministry of Physical Development and Environment and the Town Planning Board, State Emergency Management Agency of Kogi State government. The distances of building to the bank of the river were measured using GPS. Distances are measure in metres from the centroid of the building to the edge of river and roads. Simple linear regression was used to estimate the hedonic price function. The dependent variable (Y) was the sales price of building and the independent variables were: the structural, neighbourhood, environmental and flood variables. This is expressed in simple regression equation as:

Where :

$$
\mathrm{Y}=\mathrm{f}(\mathrm{X}, \mathrm{Z}, \mathrm{N}, \mathrm{F})+\mathrm{e}
$$

PRICE $=$ Sale price of houses

$\mathrm{X}=$ structural variables,

$\mathrm{Z}=$ neighborhood variables,

$\mathrm{N}=$ environmental variables, and

$\mathrm{F}=$ flood variables.

$\mathrm{E}=$ random error term.

Structural characteristics of the buildings $(\mathrm{X})$ are sales price and date, number of bedrooms, plot size and age. A total of 50 residential homes were sold in 
Lokoja between 2010 and 2012 (real estate market is not active in the area due to cultural trait). The sales prices were adjusted to August 2012 prices using a consumer price index for the houses. The average sales price was $\$ 7.2$ million naira with a minimum sales price of $\$ 1.5$ million naira and with maximum of 30 million naira. The average age of the houses is 25 years old and with plot size of 600 square metres. The Neighborhood characteristics (Z) including land uses and market segments. The areas used for the study are described as zones, which area dummy variables. Environmental characteristics (N) such as the house's location relative to the river; and flooding characteristics (F) which measures the influence of various flood-related characteristics on housing values. The floodplain is defined as an area that is likely to flood in an event of the river overflowing its bank..Table 1 defines the variables used in the hedonic model and their definitions. Summary of statistics are given in table 2. The marginal rate of substitution between flood risk and the composite goods that is the marginal willingness to pay to reduce the flood risk equal the implicit price of the flood risk.

The assumption is that each individual's utility function depends upon $\mathrm{Q}$, a composite commodity representing all goods other than housing and the housing characteristics. Then each individual will chose where to live by maximizing utility, $\mathrm{U}(\mathrm{QXZF})$ subject to a budget constrain given by $\mathrm{M}-\mathrm{P}-\mathrm{Q}=0$, where $\mathrm{M}$ is income (Bin and Polasky, 2004). Therefore the optimal choice where an individual would locate to maximize his utility would be : $\mathrm{dy} / \mathrm{dx}=-\mathrm{px} / \mathrm{py}$

The principle is in equation (2) is that given a budget constraint, a change in price has an income and a substitution effect on the quantity demanded. The substitution effect is that there would be shifts towards different locations that will enable him maximize his or her utility given his budget line or a decision to stay in that location and bear the risk rather than moving to another location. The implication of this is that the marginal effect of substitution between flood risk and the composite goods is equal to the implicit price of the flood risk. The implicit price of the flood risk is the marginal willingness to pay to reduce the flood risk.

Linear regression analysis was used to estimate the following hedonic price function:

$\log \gamma=\alpha+\beta x+\beta z+\beta n+\beta f+\varepsilon$

In equation (3), the dependent variable is the $\log$ of sales price. Also we used the natural $\log$ transformation for distance related variables (Driver and Droad) to capture the declining effects of these variables with distance. This approach was used to calculate the marginal effects to all the variables. The observed sample mean was used to calculate all the marginal effects. For all non $\log$ variables, the marginal effect for flood risk $\mathrm{dy} / \mathrm{dx}$ is equal to price times the flood risks coefficient. For distance related variables, which are $\log$ transformed, the marginal effect is price times the distance coefficient divided by the distance.

\section{Results and Discussion}

The results of the study are presented in table 3. All variable used in the analysis are statistically significant at the 95 percent confident level and have the expected sign. The coefficient on the flood risk variable (Flood risk) has negative sign and is statistically significant at 95 percent level. The estimated marginal effect for the flood variable implies that the location within the floodplain lowers the property value by an estimated 493, 408 which represents 6.8 
percent reduction in sales price for an average value house. This result confirm to the findings of Du tutu (2002) and Bin and Kruse (2006). The coefficient of house sold after the flood has a positive sign and is not statistically significant at 95 percent level. However, houses that were sold after the flood, the estimated marginal effect for an average value is higher by $\$ 217,680$ which represents only 3 percent. The results of the study are consistent with the thinking that property owners may underestimate the risks from flood if they have not had previous experience with flooding.

Based on the average value of properties, the results indicates that a property value increases by, 47.73 per additional square metres. Also an additional year of age of a property lowers the estimated value by $\$ 8,707$. 2 . In the same vein having an additional bedroom increases value by 1,7444. The study also shows that a new house sold within a year after construction increases the value by 261,941.6. One important result found in the study when flood risk variables are held constant and other variables affecting property are varied, the result indicates that proximity of houses to the rivers increases property value by 213, 563.121 and roads decrease the property value by 408,975.758. Granting that for distance related variables a negative or positive relationship to the dependent variable means that the proximity to the feature increases or decreases the property value.

The study confirms that flood events lead to higher discounts of property value. This discount depends on the location and property market situations as well as availability and cost of insurance. In Malaysia, Aliagha, et al (2014) claim that high-impact floods have become a virtually annual experience, yet flood insurance has remained a grossly neglected part of comprehensive integrated flood risk management. Whether flood risk is considered by valuers, Kropp (2014) shows that 65 percent of certificated property and valuation experts throughout Germany claim to consider flood risk within the valuation process. Wide regions of Germany were affected by floods in 2013 that caused around 12 billion of total economic costs and damages. In the same year a total of about 880 natural disasters caused insurance losses of around 90 billion euro worldwide (Munich RE, 2014). In Asia, Custom today (2015) reports that in December 2014, more than 100,000 people have been evacuated in Indonesia, 200,000 in Malaysia, and several thousand in Thailand and 1,100,000 in Sri Lanka. With more severe flooding across the world, many property owners in flood risk areas now fear that their property may be unsellable and usable. However, to make property affected by flood to be marketable, it requires re-landscaping of driveways and garden areas, raising thresholds, fitting flood-proof doors and windows, raising damp-proof courses and applying water-proof sealant to exterior walls..

\section{Conclusion}

The study uses the hedonic price method to estimate the effects of flood disaster on houses located proximal to the floodplain. The study uses Lokoja, one of the areas that were revenged by flood disaster in Nigeria in 2012. The result of the study shows that properties that are located within the floodplain are lowers in value by an average of 493, 408 which represents 6.8 percent reduction in sales price for an average value house. The results indicated that property owners and 
user are becoming aware of the inherent risk associated with living within flood prone areas. This finding contradicts several studies (Lansford and Jones, 1995; Cho, Roberts and Kim, 2011; Lewis, Bohlen and Wilson, 2008) that properties located proximity to water body's increases its value. The study suggests that there should be national insurance policy on disaster to carter for victims affected by the disaster. We recommend that effect of flood hazard on land value should be a future research priority. Also studies should be carried out on other land uses such as infrastructure (road, rail, electricity, water etc) because the make up a significant share of the damage due to flood.

\section{References}

Al-Amin, M.A. ( 2013). An assessment of Nigeria's preparedness to environmental disasters from its commitment to international environmental treaties, European Scientific Journal, 9: 242-253

Aliagha, U.G., T.E. Jin, W.W. Choong, M. Nadzri Jaafar, and H. M. Ali. (2014). Factors affecting flood insurance purchase in residential properties in Johor, Malaysia, Natural Hazards Earth System Science, 14: 32973310.

Bin, O. and Kruse, J. (2006). Real estate market response to coastal flood hazards." Natural Hazards Review, Vol 7 No. 4, pp. 137-144.

Bin, O. and Polasky, S. (2004). Effects of flood hazards on property values: evidence before and after hurricane Floyd", Land Economics, Vol.80, pp.490-500.

Cho, S., Roberts, R.K. and Kim, S.G. (2011). Negative externalities on property values resulting from water impairment: The case of the Pigeon
River Watershed', Ecological Economics, 70(12): 2390 -2399.

Clapper, J. and Caudill, S.B. ( 2014). Water quality and cottage prices in Ontario, Applied Economics, 46(10): 11221126.

Dei-Tutu, V.A. (2002). Flood hazards, insurance, and house prices - a hedonic property price analysis, department of economics", College of Arts and Sciences, East Carolina University.

Dorfman, J.H., Keeler, A.G., and Kriesel, W. (2006). Valuing risk-reducing interventions with hedonic models: the case of erosion protection, Journal of Agricultural and Resource Economics, 21(1): 109-119.

Egbenta, R. and Udo, G.O. (2013). Using contingent valuation to value non-use goods for compensation in Nigeria, Wulfenia Journal, 20(8): 473-489.

Kolawole, O.M., Olayemi, A.B and Ajayi, K.T. (2011). Managing flood in Nigerian cities: Risk analysis and adaptation options - Ilorin city as a case study, Archives of Applied Science Research, 3(1):17-24.

Kropp, S. (2014). Flood risk and property values FIG Congress: Engaging the Challenges Enhancing the Relevance Kuala Lumpur, Malaysia 16 -21 June.

Lansford, N.H. and Jones, L.L. (1995). Recreational and aesthetic value of water using hedonic price analysis", Journal of Agricultural and Resource Economics, 20(2): 341-355.

Lewis, L.Y., Bohlen, C.A. and Wilson, S. (2008). Dams, dam removal, and river restoration: a hedonic property value analysis, Contemporary Economic Policy, 26 (2):175-186.

MunichRe (2014): Reinsurance Company (www.munichre.com). 
Nigeria - Disaster Statistics 1990 -2010. Retrieved from www.emdat.be $6 / 02 / 2015$

Okagawa, A. and Hibiki, A. (2011). Estimation of perceived flood damage in Tokyo Metropolitan Area, National Institute for Environmental Studies, Tokyo Japan.

Punch, Daily Newspaper Tuesday 2013

Royal Institution of Chartered Surveyors. (2010). A clear guide to flooding for property owners; extracted on 3/09/2013 from www.rics/flooding.

Samaraweera, G. R. S. R. C., K. V. D. Edirisooriya Manike, A. S. Sandamali. (2010). The economic cost of flood in ratnapura: a case study from dewalegawa and ratnapura town, Being Conference Proceeding on International Research Conference on Sustainability in Built Environment, $18^{\text {th }}-19^{\text {th }}$ June held in Colombo, Sri Lanka.

Scawthorn, C, F. ASCE; Paul Flores; Neil Blais; Hope Seligson; Eric Tate; Stephanie Chang; Edward Mifflin; Will Thomas; James Murphy; Christopher Jones; and Michael Lawrence (2006). Hazus-mh flood loss estimation methodology. ii. Damage and loss assessment, Natural Hazards Review May

The Red Cross Society 2012

Table 1: Definition and Description of the Variables

\begin{tabular}{|l|l|}
\hline Variable & Description \\
\hline Sale price & Sales price of house adjusted to 2012 \\
\hline Zone 1 & Dummy variable for a zone (1if Galilee, 0 otherwise) \\
\hline Zone 2 & Dummy variable for a zone (1 if Adankolo, 0 other wise) \\
\hline Zone 3 & Dummy variable for a zone (1 if Old poly quarters, 0 other wise \\
\hline Zone 4 & Dummy variable for a zone (1 if Gadumo, 0 other wise) \\
\hline Zone 5 & Dummy variable for a zone (1 if Ganaja, 0 other wise) \\
\hline Age & Year house was built subtracted form 2012 \\
\hline Bedroom & Number of Bedrooms \\
\hline Tfloor & Total Floor area \\
\hline PlotS & Plot Size \\
\hline Bthroom & Number of Bathroom \\
\hline MudeH & Dummy variable for mude house (1 if house is mude, 0 other wise) \\
\hline CementH & Dummy variable for Cement block wall (1 if cement, 0 other wise) \\
\hline Vacant & Dummy variable for vacant house (1 if vacant house, 0 other wise) \\
\hline Quality & Dummy variable for good quality (1 if good quality, 0 other wise) \\
\hline Newhouse & $\begin{array}{l}\text { Dummy variable for new house (1 if sold within a year after built, } \\
\text { 0otherwise) }\end{array}$ \\
\hline Driver & Distance to River measured in metres \\
\hline Droad & Distance to Road measured in metres \\
\hline Floodrisk & Dummy Variable for flood disaster for house within flood plain \\
\hline Flood & Dummy variable for flood (1 if sold after flood, 0 other wise). \\
\hline Valid N (listwise) & Valid N (listwise) \\
\hline
\end{tabular}


Table 2 Descriptive Statistics

\begin{tabular}{|l|l|l|l|l|l|}
\hline & $\mathrm{N}$ & Minimum & Maximum & Mean & Std. Deviation \\
\hline Sale price & 50 & 1500.00 & 30200.00 & 7256.0000 & 7743.64545 \\
\hline Zone 1 & 50 & .00 & 1.00 & .4400 & .50143 \\
\hline Zone 2 & 50 & .00 & 1.00 & .1600 & .37033 \\
\hline Zone 3 & 50 & .00 & 1.00 & .2000 & .40406 \\
\hline Zone 4 & 50 & .00 & 1.00 & .0800 & .27405 \\
\hline Zone 5 & 50 & .00 & 1.00 & .1800 & .38809 \\
\hline Age & 50 & 1.00 & 25.00 & 14.6800 & 7.46814 \\
\hline Bedroom & 50 & 1.00 & 8.00 & 3.5000 & 1.83225 \\
\hline Tfloor & 50 & 20.00 & 267.05 & 138.4114 & 78.24903 \\
\hline PlotS & 50 & 300.00 & 600.00 & 429.6000 & 123.83267 \\
\hline Bthroom & 50 & 1.00 & 4.00 & 1.8800 & .93982 \\
\hline MudeH & 50 & .00 & 1.00 & .1200 & .32826 \\
\hline CementH & 50 & .00 & 1.00 & .8800 & .32826 \\
\hline Vacant & 50 & .00 & .00 & .0000 & .00000 \\
\hline Quality & 50 & .00 & 1.00 & .9200 & .27405 \\
\hline Newhouse & 50 & .00 & 1.00 & .3600 & .48487 \\
\hline Driver & 50 & .10 & 2.50 & .5640 & .60363 \\
\hline Droad & 50 & .10 & .96 & .3300 & .28035 \\
\hline Floodrisk & 50 & .00 & 1.00 & .5000 & .50508 \\
\hline Flood & 50 & .00 & 1.00 & .5600 & .50143 \\
\hline Valid N (listwise) & 50 & & & & \\
\hline
\end{tabular}

Note: The total number of observation is 50 .

Table 3 Estimation Result of the Hedonic price Function

\begin{tabular}{|c|c|c|c|c|c|}
\hline \multirow{2}{*}{\multicolumn{2}{|c|}{ Variable }} & \multicolumn{2}{|c|}{$\begin{array}{l}\text { Unstandardized } \\
\text { Coefficients }\end{array}$} & \multirow[b]{2}{*}{ Sig. } & \multirow{3}{*}{ Marginal Effects } \\
\hline & & $\mathrm{B}$ & Std. Error & & \\
\hline \multirow[t]{18}{*}{1} & (Constant) & 3.315 & 0.116 & 0 & \\
\hline & Zone 1 & -0.022 & 0.049 & 0.664 & -159.632 \\
\hline & Zone 2 & -0.032 & 0.055 & 0.562 & -232.192 \\
\hline & Zone 3 & -0.053 & 0.056 & 0.352 & -384.568 \\
\hline & Zone 4 & -0.112 & 0.061 & 0.077 & -812.672 \\
\hline & Zone 5 & -0.052 & 0.044 & 0.246 & -377.312 \\
\hline & Age & -0.012 & 0.004 & 0.004 & -87.072 \\
\hline & Bedroom & 0.024 & 0.022 & 0.282 & 174.144 \\
\hline & Tfloor & 0.002 & 0.001 & 0.017 & 14.512 \\
\hline & PlotS & $6.58 \mathrm{E}-05$ & 0 & 0.751 & 0.4773 \\
\hline & Bthroom & -0.037 & 0.035 & 0.293 & -268.472 \\
\hline & CementH & -0.076 & 0.038 & 0.055 & -551.456 \\
\hline & Quality & 0.196 & 0.051 & 0.001 & 1422.176 \\
\hline & newhouse & 0.361 & 0.057 & 0 & 2619.416 \\
\hline & Driver & 0.166 & 0.048 & 0.002 & 1204.496 \\
\hline & Droad & -0.186 & 0.05 & 0.001 & -1349.62 \\
\hline & Floodrisk & -0.068 & 0.034 & 0.052 & -493.408 \\
\hline & Flood & 0.03 & 0.026 & 0.262 & 217.68 \\
\hline
\end{tabular}

Notes: Dependent variable is the log of sale price. Adjusted R-square is .976 . Marginal effects are evaluated at the observed means. 
Using Hedonic Price Model to Estimate Effects of Flood on Real Property Value................EGBENTA et al.

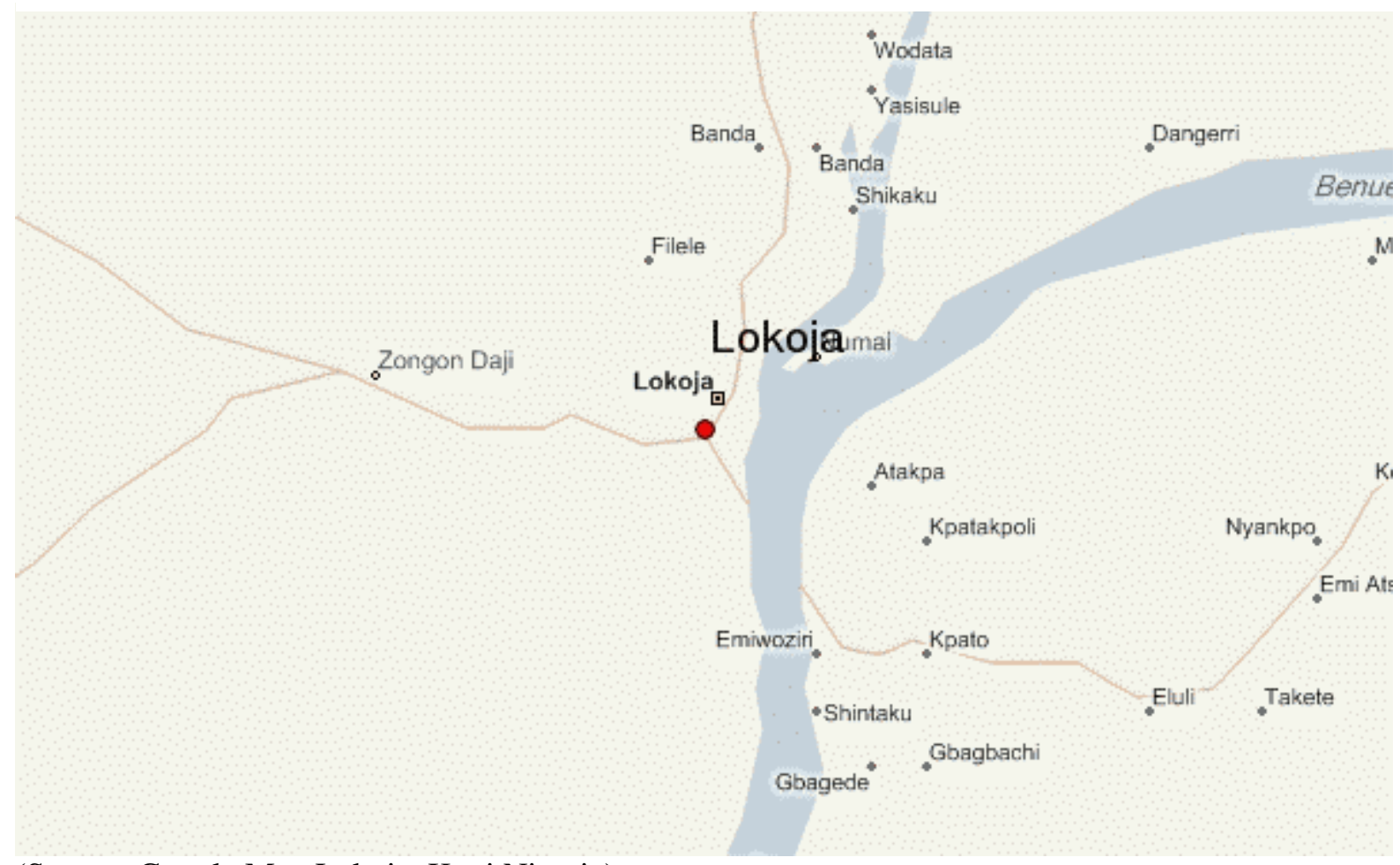

(Source: Google Map Lokoja, Kogi Nigeria)

Figure 1 represents a map showing the floodplain as well as study area 